\title{
Exploring Positionality in an Aboriginal Research Paradigm: A Unique Perspective
}

\author{
Michele Moffat \\ University of Prince Edward Island, Canada
}

\begin{abstract}
In this paper I explore questions related to the epistemological and ontological differences existing between Euro-Western and Indigenous ways of knowing. Revealing myself to the reader through positioning, I explore the possibility of reaching an ethical middle ground, while occupying an unearned position of privilege. In doing so, I discuss the personal process of decolonization and its location within my research. Drawing on the works of Indigenous scholars, I discuss the potential for a neutral, ethical, space-bridging worldview. In conclusion, I highlight details about how meaningful knowledge creation can aid a non-Aboriginal researcher engaged in an Aboriginal research paradigm.
\end{abstract}

\section{Introduction}

I start this document with a disclaimer. I am not formally a member of any First Nations community, and I do not pretend to really know or understand the lived experiences of Aboriginal peoples. I am not an Aboriginal person (later in this document, I present a caveat pertaining to this statement). It is not my intention to suggest that I possess some type of deep, personal insight about Indigenous epistemology and culture. I agree with Weber-Pillwax [1], who stated that it is not possible for a person to perceive of something they do not know. Merely wanting to have my thinking align with Indigenous worldviews and ways of knowing does not mean that I am able to fully understand Indigenous views of life. Moreover, I recognize that I will never be able to fully understand Indigenous realities, because I have never lived them. Clearly, much research [2], [3], [4] spotlights the importance of the researcher possessing background experience connected to the focus of the research. Why, then, would I try to study an issue that I will never be able to fully grasp or comprehend? This paper allows me to share where I come from, describe who I am now, and articulate where I want to go. It is through this transparency that I position myself as a non-Aboriginal, preparing to do Aboriginal research.

In essence, the purpose of this paper is to explore questions related to the epistemological and ontological differences existing between EuroWestern and Indigenous ways of knowing, and to reflect on my non-Aboriginal positionality with regard to these philosophies. Revealing myself to the reader through positioning, I explore the possibility of reaching an ethical middle ground, while simultaneously occupying an unearned position of privilege. In doing so, I discuss the personal process of decolonization and its location within my research. Drawing on the works of Indigenous scholars, I discuss the potential for a neutral, ethical, space-bridging worldview. In conclusion, I draw attention to final details about how meaningful knowledge creation can aid a non-Aboriginal researcher engaged in an Aboriginal research paradigm.

\section{White Privilege and Colonialism}

As an educated White woman, I write from an unearned position of privilege. As such, I cannot fully embody the essence of Indigenous epistemology. While I acknowledge that my cultural lens limits my awareness of other ways of knowing, I believe in more than one truth and in many ways of knowing. I am actively engaged in a self-process of decolonization and a move in the direction of an evolving personal epistemology, discovering new ways to define knowledge. As I begin my research, I hope to undergo an epiphany of self. By reflecting on the notion that the universe is within me and that I am in the universe, a genesis of self-epistemology is welcomed. More specifically, as I explore the universe within myself, including examinations of DNA influences, I also begin to deepen my spirituality; a process which I believe is needed to conduct quality, ethical research pertaining to Indigenous topics. As Churchill [5] articulated, I wish to examine the interdependence of myself and the world as it exists within and beyond me. I seek to 
view the larger picture as all things exist relative to each other and develop a deeper awareness of their relationality. To the same extent, I wish to lay myself open to you, the reader, through this thorough dissection of myself. In turn, demonstrating my positionality is the first step in engaging in an ethical research methodology within an Indigenous research paradigm.

Said [6] stated that all cultures are intertwined. He described the ubiquitous presence of empiricism and proposed that, regardless of our cultural epistemology, "We can characterize our own present attitudes: the projection, or the refusal, of the wish to dominate, the capacity to damn, or the energy to comprehend and engage with other societies, traditions, histories". I acknowledge that I am an outsider who desires to conduct research in the area of Indigeneity. I realize that in order to do so I need to start with self-reflection. I must come face-to-face with aspects of my culture, my core beliefs, and my fundamental values, and decipher them. I must reexamine my personal ontology, my beliefs about reality, and the hegemonic influences that have influenced my values pertaining to life and its interconnected relationships. As a result, this academic and spiritual undertaking must begin by both defining and redefining myself and scrutinizing the cultural and societal underpinnings that create my worldview.

I recognize that there is more than one way of knowing, and there is more than one truth. Tafoya [7] indicated that the influence of culture is embodied in the ways human beings perceive and interpret the world. He stated that cultures vary in the basic value placed on their approach to and assessment of information. He illustrated this point by describing the way in which people interpret what they see when gazing at the moon in the sky. For example, culture describes this planetary object as the man in the moon to White people, the rabbit in the moon to ancient Chinese cultures, and the frog in the moon to Native people in the Northwest. Although people share a similar empirical reality, it is within and through the epistemological lens of culture that identical experiences become translated into diverse meanings.

Aligned with the above discussion of a nonAboriginal conducting Aboriginal research, I reflect upon the ideas of Paulo Freire [8]. Although it is not within the scope of this paper to present an in-depth analysis of Paulo Freire and his views on social justice, it is beneficial to consider his view on the oppressed and how it relates to Aboriginal issues in research. Friere's view on the oppressed can be transposed to the topic of how subjectivity and objectivity relate to personal ontology. He discussed the need for equilibrium between the objective and subjective in critical inquiry and explained that extremes on either side cannot preserve a balanced view of the world. Friere suggested that neither a subjective reality nor an objective reality could be envisioned without the other, suggesting that an ongoing communication must exist between the two. More specifically, he stated:

To deny the importance of subjectivity in the process of transforming the world and history is naïve and simplistic. It is to admit the impossible: a world without people. This objectivistic position is as ingenious as that of subjectivism, which postulates people without a world. World and human beings do not exist apart from each other, they exist in constant interaction.

This quote emphasizes the value in maintaining a balanced reality in pursuit of equilibrium between objective and subjective influences in the world. I am a non-Aboriginal researcher and my personal ontology was influenced by a Euro-Western colonialist hegemony that favors empirical research. As I undertake this critical inquiry, I begin my search for a balanced approach, harmonizing the subjective and the objective, seeking to locate myself within the process, and recognizing that, as Graveline wrote, "Eurocentrism is at best an approximation of reality rather than an accurate image of it" [9].

Steinhauer [10] cautioned that limitations are held within the very process of defining. These limitations restrict the possibilities of creating new ways of knowing and understanding. The Western colonialist hegemony, which calls for objective and empirical inquiry, exists in opposition to an epistemology that honors multiple ways of knowing. Tafoya [7] explained that judgment is inherent in the Western process of inquiry: "If you don't believe the way that I believe, then all I have to do is give you more data, and you will convert to believing the way that I believe". This epistemology reflects a set of priorities grounded in empiricism and does not allow for more than one truth. The Eurocentric hegemony of colonial, scientific thought reflects what Friere [8] termed "a world without people". I believe this hegemony represents a self-limiting perspective where core beliefs eliminate the possibility of new and alternative ways of knowing. Unequivocally, I cannot step outside of the Western worldview in which I grew up. My personal ontology was inherently shaped by colonial influences, and I am responsible for examining the ways in which my beliefs have the potential to impact my research. Haig-Brown [11] described the broad reaches of 
colonialization across time and geography, emphasizing the effort and time commitment required to work toward cultural equilibrium. As a White academic engaged in Aboriginal research she suggested a focus toward deliberately addressing the influences of colonization and described "a process we can embrace and teach our children". As a White researcher, I too aspire to this process. Despite the fact that I am an outsider who, like Haig-Brown, cannot fully understand Indigenous realities, I believe the potential for research partnerships is not diminished. I believe that cross-cultural partnerships forged today create the potential for broadened understanding, respect, and reverence for other ways of knowing, now and in future generations.

Blaut [12] described dominant Eurocentric culture as designed to sustain an everlasting supremacy over all other cultures. This hegemonic purview creates binary opposites, where the Inside consists of Eurocentric innovators, and the Outside is compiled of non-European imitators. Blaut stated these contrasting forces establish the underpinning constructs of Eurocentric diffusionism, where cultural practices follow a natural flow from innovator to imitator. From this perspective, actions originate with the dominant Insider, while Outsiders remain as beneficiaries of dominant cultural practices. Moreover, it is in this diffusionism that the pedagogical underpinnings of the present Canadian educational system were created. At this time, while I am examining my own culpability in maintaining colonialist hegemonic power structures, my views are changing regarding social justice, history, culture, education, and knowledge. I am interested in the means by which power relationships drive and shape the very structures built and designed to maintain colonialist domination. I acknowledge that colonialist epistemology has wreaked havoc on Indigenous cultures globally. The historical, cultural, pedagogical, ethical, and personal myths and illusions residing therein have served to oppress and marginalize Indigenous people [1], [9], [10], [12], [13]. The processes related to colonization have denied a voice to Indigenous people and rejected Indigenous beliefs and ways of knowing.

Historically, Western colonial researchers conducted empirical inquiries by entering into Aboriginal communities, peering through EuroWestern research lenses, and passing judgment on beliefs they were not cultured to understand or interpret [2], [3]. Research results were used in unethical ways, often resulting in negative impacts on the people and communities who participated in empirical studies [13]. A Euro-Western and empiricist approach to research remains out of step with Aboriginal epistemology and ontology. Researchers currently involved in Aboriginal research bear the weight of this legacy, creating the necessity for their engagement in a vigorous and ongoing reflective process [4], [14]. O’Connor [14] discussed the importance of thorough consideration for motivations regarding why a non-Aboriginal researcher wishes to engage in research partnerships in Indigenous communities. I fully acknowledge that, as a White researcher entering into an Aboriginal research paradigm, it is necessary to clearly examine and reflect on my own educational, personal, and spiritual motivations for engaging in this type of research partnership. Regardless of my desire to respect Aboriginal ways of knowing and to participate in beneficial research, I am powerless to control what I cannot know, and blind to what I cannot see. I envision myself evolving on every level, with body, mind, and spirit engaged in a circular, overarching, reflexive practice with no beginning and no end. It must permeate and inform all aspects of past, present, and future as I evolve in my dissertation journey. Through this manner of ethical practice I can begin to redress the legacy I inherit as a non-Aboriginal researcher engaged in Aboriginal purpose.

\section{Positionality: Locating Myself}

Understanding that all things in life begin with self, it seems appropriate to start this research process with a deeper explanation of who I am personally, professionally, emotionally, and spiritually. I want to highlight that there are obvious aspects of myself that are publically known and easy to share; however, there are also aspects of my being that are sacred and personal to me and not publicly visible. I appreciate Absolon and Willett's (2004) statement that positioning of one changes based on the work being done and on the aspects of one's own location that most resonate with the goals of the current project [15]. I might add that the audience also influences the positioning of oneself. For this research, I believe it is important to give as much as possible, both personal information and what I perceive to be some sacred details of my personal life. Here, the audience to whom I need to be transparent is both the reader and Aboriginal communities with whom I hope to conduct research.

I believe the lived experiences from my childhood add to my sensitivity and awareness as an adult. I was raised in Fredericton, New Brunswick. My birth father abandoned my mother, my 5-yearold sister, and me when I was 8 months old. I did not meet him again until I was 17 years of age. As a child growing up without a father, I felt an elemental 
piece of myself was missing. People who knew my father often told me that characteristics of my nature and personality mirrored his. The similarity between my father, whom I had no memories of, and myself was pointed out to me many times as a child. As a result, I began to ask myself a fundamental question: How can someone display similarities as intimate as personality traits with another person to whom they have almost no connection, other than through shared genetics? I believe there are certain bonds between people as human beings that potentially exist beyond knowledge or culture, and I believe people can explore, experience, and celebrate these shared connections.

In other words, in my perception, cultural explorations are not off-limits. These pursuits may be one means of finding common ground and bridging understanding of other ways of being and knowing. Perhaps as a precursor to undertaking this personal journey into research, I started an inward journey of a more spiritual nature. In the 1960s, no other child in our close-knit Catholic community was raised without his or her father. In my earliest experiences of attending church and school, I cannot recall anyone whose parents were divorced. I had no role models for this situation and no one to talk to about my absent father. Out of this unique set of experiences I developed a sense of not belonging. What I learned at church, at school, and through observation of the children and families in my community was incongruent with my own life. I distinctly recall that my questions about my father made the adults around me uncomfortable and I was openly discouraged from asking about my family history as it related to my father. As an adult reflecting on my childhood years, I realize the people I most trusted in my life told me many untruths and half-truths. As a child, I did not have the means to independently seek out answers. In my adulthood, I became curious to know and understand who I was in new ways, seeking answers that were not available to me as a child. I was not searching for anything specific, but felt that I had a right to know who I was without another person's judgment clouding the accuracy of information I received. Given the failure of my earliest experiences related to discovering my origins, I believed that a reliable way of confirming my genetic background would be through exploring scientific evidence, so I took a test to identify my genetics based on DNA. At 51 years of age I discovered that I have more Sub-Saharan Black African and Aboriginal DNA than I have European DNA. In turn, I own this one truth-my bones are irrefutably made up of African, Aboriginal and European genetic material. With this scientific truth, am I still a non-Aboriginal person engaged in Aboriginal research?

\section{My White Privilege Meets my Aboriginal DNA}

Having revealed myself to the reader, I wish to state that in exposing details of myself, my life, and my DNA, more questions emerge. I have related part of my colonialist cultural identity and have begun my self-analysis and decolonization. The pursuit of self-truth is a result of my evolving epistemological views, producing a new depth to my personal and research-related questions. Since the time of the Enlightenment, influential Euro-Western philosophers Jean-Jacques Rousseau, Immanuel Kant, John Stuart Mill, Charles Darwin, and others have claimed that the only reliable truth exists in scientifically measurable fact, leaving no room and no credence for spiritual beliefs. I do not believe empirical evidence is the only source of reliable truth and knowledge. I have had many personal experiences that I cannot explain based on the value system used by my culture. I perceive the empiricist pursuit of one truth to be an insufficient, manacled approach to comprehending the vast complexities of life, spirituality, and the universe.

I am aware of the irony in discussing my own empirically measured DNA evidence at the same time that I reveal my decolonized epistemology. However, I believe authentic self-awareness can potentially grow through a crystallized approach to reflexivity. I concur with Chilisa, that to become an ethical researcher it is imperative to "critically reflect on self as knower, redeemer, colonizer, and transformative healer". I wish to plainly state that I am not comfortable in viewing myself in each of the described roles; nevertheless, I must undertake the process and willingly reflect on who I am, on my own epistemology, and on the cultural, political, and pedagogic forces that have shaped me.

I have stated that my cells are braided together with three clearly defined types of DNA: SubSaharan Black African, Aboriginal, and European. Although the purposes of this paper are not to investigate the scientific or philosophical issues connected to this testing, I wish to acknowledge a number of the shadowy aspects of my statement. As Tallbear articulated the use of scientific measures of DNA raise significant suspicion around whether such means could actually be employed to exclude Indigenous people from their rights to Indigenous status, or be used by outsiders to claim rights to unearned tribal support and status [13]. I acknowledge the threat posed both by government 
forces using this technology to further marginalize Indigenous people and the potential for people who have no tribal or community connection to seek rights or relationships based on what is measured in their DNA. I unequivocally state that I believe my DNA does not automatically give me license to make claims, to seek rights, or to ask for considerations in any way. I should not be trusted unless my actions earn trust. Other than my right to speak the truth of who I am, I claim nothing. I cannot and do not wish to speak for others. Culturally, I am not an Aboriginal or an African person; I am a privileged White woman who may be a living example of the colonialist agenda. I have no connection to my DNA inheritance, and I have no way of finding those roots. I return to my original question of whether it is ethical for a non-Aboriginal person to participate in Aboriginal research. As I seek an ethical space, I share with you the words of Rita Bouvier from her moving forward to Marie Battiste's book, Decolonizing Education: "An ethical space is a theoretical space created among human communities for retreat, reflection, and dialogue to share understandings and to work together to create a shared future" [14]. I am inspired by the work of Willie Ermine, who discussed creating a new and dynamic ethical space where Indigenous and EuroWestern epistemologies can be acknowledged and respected as researchers work together to form meaningful collaborations [17]. In essence, I cannot use scientific DNA results as a form of ultimate truth, because one fundamental reality does not exist. However, I can use both self-growth and DNA awareness to create a more comfortable ethical space with regard to a non-Aboriginal doing Aboriginal research.

I experience a deep sadness as I reflect on the global history of Indigenous people. In Canada, the history of colonization is associated with disease, the terror of residential schools, the loss of Indigenous culture and language, and the incredible pain that comes with that loss. Throughout the centuries, the aim of colonization has never wavered [2], [3], [6], [9], [18]. Pernicious colonialist forces act to create future generations who forget their past and assimilate without question into dominant power structures. In order to advance the political agenda of Canada and remove Indigenous people from their lands, the Canadian political system implemented the Indian Act in 1867. The government set out to determine who is Indian, establishing a very narrow definition of qualification for the designation. The Indian Act was a political agenda employed by the government of Canada to further marginalize and deny rights to thousands of human beings who had always identified themselves as Indigenous. The silencing of Indigenous voices resonates loudly in the history of Canada [4], [14], [18], [20].

Jessica Kopolynuk (2014) wrote a touching article to her future daughter explaining why she is not Indian in spite of her clear Cree ancestry: "In our family, we have not met the original criteria set out by the Act for three generations, and so that definition alone has, unfortunately, perforated our experiences and history with a legacy of exclusion" [18]. As I read Kolopynuk's letter to her daughter, I find myself reflecting on my ancestry. I try to imagine the lives of the African, European, and Indigenous women to whom I am genetically bound. I do not know if the Indian Act excluded my family; however, I may be living evidence that it did. I admit I am removed from the culture, language, and traditional values of my ancestors, but no political agenda can remove my DNA. Due to the experiences from my childhood, I understand the profound sense of loss people bear within themselves when removed from their closest family ties. I feel the intensely dichotomous impacts of being physically removed from while simultaneously spiritually connected to my ancestry. I carry within me a profound sense of responsibility as a human being and as a researcher to conduct myself in a way that honors all elements of my ancestry.

At this point, I have many more questions than answers. Where is my African family? What were their lived experiences? Were they removed from their culture through assimilation and thrown into globally dominant colonialist political power structures? Did they grieve the disconnection from their precious children who would be born into an unknown future and inherit the legacy of an unknown past? I like to believe my African and Aboriginal ancestors drew strength from their cultural and spiritual beliefs. Although Indigenous epistemologies differ greatly from each other, they are bound together by an overarching spiritual knowledge that everything in the universe is connected [2], [3], [4]. This deep spiritual reverence for the connectedness of all things is absent in Western colonialist hegemony.

In conclusion, I ponder one final question. On this planet in this moment there are people who culturally identify as African and Indigenous and yet are braided together just as myself, with a variety of DNA influences. How do we come together to reach beyond the limits of cultural and epistemological values and overcome the boundaries of hegemony with the goal of establishing a common ground where we can work shoulder to shoulder in an ethical space for social justice? I agree with Bouvier who posited "the common ground might be an 
understanding that we are all part of something greater than our differences" [19].

\section{References}

[1] Weber-Pillwax, C. (2001). What is Indigenous research? Canadian Journal of Native Education, 25(2), 166-174.

[2] Chilisa, B. (2012). Indigenous research methodologies. Thousand Oaks, CA: Sage.

[3] Smith, L. T. (2012). Decolonizing methodologies: Research and Indigenous peoples (2nd ed.). London, England: Zed Books.

[4] Wilson, S. (2008). Research is ceremony: Indigenous research methods. Halifax, NS: Fernwood.

[5] Churchill, A. H. (2008). Rocking your world: The emotional journey into critical discourses. Rotterdam, Taipei: Sense.

[6] Said, E. W. (1993). Culture and imperialism. New York, NY: Random House.

[7] Tafoya, T. (1995). Finding harmony: Balancing traditional values with Western science in therapy. Canadian Journal of Native Education, 21(Supplement), 55-60.

[8] Freire, P. (2000). Pedagogy of the oppressed. New York, NY: Continuum International.

[9] Graveline, F. J. (1998). Circle works: Transforming Eurocentric consciousness. Halifax, NS:Fernwood.

[10] Steinhauer, E. (2002). Thoughts on an Indigenous research methodology. Canadian Journal of Native Education, 26(2) 69-81, 201.

[11] Haig-Brown, C. (2000). Taking down the walls: Communities and educational research in Canada's 21st century. NALL Working Paper \#17-2000. Retrieved from: http://nall.oise. utoronto.ca/res/ 17takingdown.htm (Access date: 20 June, 2014).

[12] Blaut, J. M. (1993). The colonizer's model of the world: Geographical diffusionism and Eurocentric history. New York, NY: Guilford Press.

[13] TallBear, K. (2013). Genomic articulations of Indigeneity. Social Studies of Science, 43(4), 509534.

[14] Battiste, M. (2013). Decolonizing education: Nourishing the learning spirit. Saskatoon, SK: Purich.

[15] O'Connor, K. B. (2008). Challenging paradigms: Deconstructing and reconstructing my positionality as a non-Indigenous researcher. In A. H. Churchill (Ed.), Rocking your world: The emotional journey into critical discourses (pp. 67-80). Boston, MA: Sense.

[16] Absolon, K., \& Willett, C. (2004). Aboriginal research: Berry picking and hunting in the 21st century. First Peoples Child \& Family Review 1(1), 5-17.

[17] Ermine, W. (2007). The ethical space of engagement. Indigenous Law Journal, 6(1), 193-203.

[18] Kopolynuk, J. (2014). My girl. Aboriginal policy studies online journal, 3(3), 109-114.

[19] Bouvier, R. (2013). Foreword. In M. Battiste, Decolonizing education: Nourishing the learning spirit (pp. 8-12). Saskatoon, SK: Purich.

[20] The Truth and Reconciliation Commission of Canada (2015). Honouring the Truth, Reconciling for the Future: Summary of the Final Report of the Truth and Reconciliation Commission of Canada. Retrieved from: http://www.trc.ca/websites/trcinstitution/in dex.php?p=893 (Access date: 21 July 2014). 